\title{
Monitoring of atmospheric composition using the thermal infrared IASI/MetOp sounder
}

\author{
C. Clerbaux ${ }^{1,2}$, A. Boynard ${ }^{1,3}$, L. Clarisse ${ }^{2}$, M. George ${ }^{1}$, J. Hadji-Lazaro ${ }^{1}$, H. Herbin ${ }^{2,}{ }^{*}$, D. Hurtmans ${ }^{2}$, M. Pommier ${ }^{1}$, \\ A. Razavi ${ }^{2}$, S. Turquety ${ }^{1, * *}$, C. Wespes ${ }^{2}$, and P.-F. Coheur ${ }^{2}$ \\ ${ }^{1}$ UPMC Univ. Paris 06 ; Université Versailles St.-Quentin ; CNRS/INSU, LATMOS-IPSL, Paris, France \\ ${ }^{2}$ Spectroscopie de l'Atmosphère, Chimie Quantique et Photophysique, Université Libre de Bruxelles (U.L.B.), \\ Brussels, Belgium \\ ${ }^{3}$ Université Paris 12 et 7; CNRS/INSU, LISA-IPSL, Créteil, France \\ *now at: Laboratoire d'Optique Atmosphérique, Université des Sciences et Technologies de Lille, \\ Villeneuve d'Ascq cedex, France \\ ${ }^{* *}$ now at: UPMC Univ. Paris 06; CNRS/INSU, LMD-IPSL, Paris, France
}

Received: 20 February 2009 - Published in Atmos. Chem. Phys. Discuss.: 30 March 2009

Revised: 21 July 2009 - Accepted: 28 July 2009 - Published: 20 August 2009

\begin{abstract}
Atmospheric remote sounding from satellites is an essential component of the observational strategy deployed to monitor atmospheric pollution and changing composition. The IASI nadir looking thermal infrared sounder onboard MetOp will provide 15 years of global scale observations for a series of key atmospheric species, with unprecedented spatial sampling and coverage. This paper gives an overview of the instrument's capability for measuring atmospheric composition in the perspective of chemistry and air quality. The assessment is made in terms of species, accuracy and vertical information. Global distributions are presented for $\mathrm{CO}$, $\mathrm{CH}_{4}, \mathrm{O}_{3}$ (total and tropospheric), $\mathrm{HNO}_{3}, \mathrm{NH}_{3}$, and volcanic $\mathrm{SO}_{2}$. Local distributions of organic species measured during fire events, such as $\mathrm{C}_{2} \mathrm{H}_{4}, \mathrm{CH}_{3} \mathrm{OH}, \mathrm{HCOOH}$, and PAN are also shown. For each species or process, the link is made to specialized papers in this issue.
\end{abstract}

\section{Introduction}

Measurement of atmospheric composition from space is challenging but remote sensing sounders offer a unique perspective on the state of our environment, from short to long

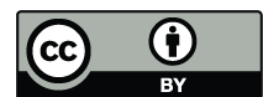

Correspondence to: C. Clerbaux (cathy.clerbaux@latmos.ipsl.fr) term, and on a local to global scale. Several remote sensors that use the Earth's or the atmosphere's thermal emission, reflected solar radiation, or solar radiation itself, have demonstrated their ability to provide relevant information for the study of changing local air quality (e.g. Richter et al., 2005; Martin, 2008), long-range transport of pollutants (e.g. Edwards et al., 2006), emission sources (e.g. Frankenberg et al., 2008) and climate change issues (e.g. Worden et al., 2008). The preparation for such satellite missions starts long before the launch, whilst the scientific return and societal benefit can only be evaluated when products delivered by the instruments become available. The whole process extends over years and includes a comprehensive preparation phase for designing the concept of a mission which addresses specific scientific needs, an industrial phase for building the instrument according to observational requirements, and a consolidation phase for accommodating the instrument on a platform.

Among the existing thermal infrared (TIR) spaceborne instruments devoted to tropospheric remote sensing, the Infrared Atmospheric Sounding Interferometer (IASI) has a special status as it combines the heritage of instruments dedicated to weather forecasting (e.g. the High-resolution Infrared Radiation Sounder, HIRS, and the Atmospheric InfraRed Sounder, AIRS) with that of tropospheric sounders dedicated to atmospheric chemistry and climate (e.g. the Interferometric Monitor for Greenhouse gases, IMG, the Tropospheric Emission Spectrometer, TES, the Atmospheric

Published by Copernicus Publications on behalf of the European Geosciences Union. 
Chemistry Experiment, ACE-FTS, and the recently launched GOSAT mission). In the case of IASI, the instrument design resulted from compromises between the meteorology requirements (high spatial coverage) and the atmospheric chemistry needs (accuracy and vertical information for trace gases). This led to the development of an advanced instrument based on a Fourier Transform Spectrometer (FTS) that was designed by the Centre National d'Etudes Spatiales (CNES) (Cayla, 1993; Blumstein et al., 2004) and combines good horizontal coverage with a moderate spectral resolution. IASI is now operating from the MetOp-A meteorological payload launched by Eumetsat in October 2006 in a polar orbit. The prime objective of the MetOp mission is to deliver continuous, long-term data sets to support operational meteorology, environmental forecasting and global climate monitoring.

MetOp is the space segment of the Eumetsat Polar System (EPS), which initiates the European contribution to a joint Europe-US suite of satellites. The MetOp payload provide the mid-morning service (at a mean local solar time of 09:30), while the US satellite will provide the afternoon service. The MetOp program consists of a series of three satellites, to be launched sequentially every 5 years in order to provide observations for more than 15 years. MetOpA consists of a set of state-of-the-art sounding and imaging meteorological instruments (Advanced TIROS Operational Vertical Sounder, ATOVS, Advanced SCATterometer, ASCAT, Advanced Very High Resolution Radiometer, AVHRR, Microwave Humidity Sounder, MHS, Advanced Microwave Sounding Unit-A, AMSU-A) along with two advanced atmospheric chemistry passive remote sensors: IASI and the Global Ozone Monitoring Experiment-2 (GOME-2) (Callies et al., 2000), that allow atmospheric composition measurements in a near-real time operational mode. The MetOp missions can also be considered as a first step for the Earth observation space segment of the Global Monitoring for Environment and Security (GMES) initiative, a concerted effort from the European Union and the European Space Agency to bring data and information providers together with users, based on satellite observations and ground based measurements.

Early evaluation of the IASI products is necessary as the post-EPS program (polar orbiting satellites to be launched as follow-up of the MetOp program after 2019) is already in an advanced phase. In particular, the added value of near real time and global coverage products relevant for atmospheric chemistry need to be evaluated, as the instrumental specifications of the sensors onboard post-EPS are currently being decided. This paper reviews the capability of IASI to measure atmospheric composition, relying on research activities from different groups undertaken since the launch. It is organized as follows: we first describe the IASI mission, and then we report on the retrieval of global scale total columns and profiles for a series of infrared absorbing species, along with their characterization in terms of vertical information and ac- curacy. The focus here is on species that are relevant to the chemistry, leaving aside the ones of significance for climate studies. In conclusion we highlight the advantages of the IASI mission in the European GMES initiative framework.

\section{The IASI/MetOp mission}

The main characteristics of the IASI instrument and of the MetOp platform are summarized in Table 1.

\subsection{Instrumental design and orbit}

IASI consists of an FTS associated with an imaging instrument. It is designed to measure the spectrum emitted by the Earth-atmosphere system in the TIR spectral range, using nadir geometry. Measurements are performed from the MetOp polar orbit, at an altitude of around $817 \mathrm{~km}$. The satellite is sun-synchronous with a $98.7^{\circ}$ inclination to the equator, and the satellite's ground track is at about 09:30 local time in the morning (and 21:30 in the evening). The time to complete an orbit is about $101 \mathrm{~min}$, which implies that MetOp makes a little more than 14 orbits a day.

\subsection{Horizontal coverage}

To achieve global coverage, the IASI instrument observes the Earth up to an angle of $48.3^{\circ}$ on both sides of the satellite track. This corresponds to $2 \times 15$ mirror positions and a swath of about $2 \times 1100 \mathrm{~km}$. Each instantaneous field-ofview $\left(3.3^{\circ} \times 3.3^{\circ}\right.$ or $50 \mathrm{~km} \times 50 \mathrm{~km}$ at nadir) is composed of $2 \times 2$ circular pixels, each corresponding to a $12 \mathrm{~km}$ diameter footprint on the ground at nadir (see Fig. 1).

\subsection{Spectral range}

The instrument uses several detectors to fully cover the spectral range that extends from 645 to $2760 \mathrm{~cm}^{-1}$ (15.5 to $3.62 \mu \mathrm{m})$. The spectral range was chosen to include the strong absorption features from the $\mathrm{CO}_{2}$ absorption band around $15 \mu \mathrm{m}$ (used for temperature profile retrievals), the ozone $9.6 \mu \mathrm{m}$ band, the strong water vapour $\nu_{2}$ absorption band, and up to the edge of TIR in the $\mathrm{CH}_{4} \nu_{3}$ absorption band. It is worth noting that the signal recorded by the instrument contains a contribution from solar backscatter for wavenumbers $>2000 \mathrm{~cm}^{-1}$. Many other molecular absorptions occur within the IASI spectral range, from which the concentration of trace gases are retrieved (see Sect. 3.1). In addition, surface and cloud properties are derived from transparent windows.

\subsection{Radiometric noise and spectral resolution}

The IASI Level 1 processing generates calibrated and apodized atmospheric spectra (Level 1C data) from raw interferograms. The raw spectra are of high radiometric quality, with a noise equivalent temperature difference lower than 
Table 1. Characteristics of the MetOp satellite and of the IASI instrument.

\begin{tabular}{|c|c|}
\hline Metop A & Launched on October 19, 2006 \\
\hline Altitude & $\sim 817 \mathrm{~km}$ \\
\hline Orbit & Polar sun-synchronous \\
\hline Inclination & $98.7^{\circ}$ to the equator \\
\hline Local time & $\sim 09: 30$, descending orbit \\
\hline Time for one orbit & $101 \mathrm{~min}$ \\
\hline Repeat cycle & 29 days (412 orbits) \\
\hline IASI & Fourier transform spectrometer \\
\hline Size and weight & $1.7 \mathrm{~m}^{3}, 236 \mathrm{~kg}$ \\
\hline Spectral range & 645 to $2760 \mathrm{~cm}^{-1}$ \\
\hline Spectral resolution & $0.3-0.5 \mathrm{~cm}^{-1}\left(0.5 \mathrm{~cm}^{-1}\right.$ apodized $)$ \\
\hline Radiometric noise & $<0.1-0.2 \mathrm{~K}\left(650-1750 \mathrm{~cm}^{-1}\right)$ \\
\hline$(\mathrm{Ne} \Delta T$ at $280 \mathrm{~K})$ & $0.2-0.4 \mathrm{~K}\left(1750-2500 \mathrm{~cm}^{-1}\right)$ \\
\hline Scan type & Step and dwell \\
\hline Field of view & $\begin{array}{l}50 \mathrm{~km}\left(3.33^{\circ}\right) \text { at nadir, } \\
\text { with } 4 \text { simultaneous pixels of } 12 \mathrm{~km}\end{array}$ \\
\hline Full swath width & $\sim 2200 \mathrm{~km}\left( \pm 48.3^{\circ}\right), 120$ pixels \\
\hline Global Earth coverage & 2 times per day \\
\hline Data rate & $\begin{array}{l}1.5 \mathrm{Mbps} \text { (after onboard processing), } \\
120 \text { radiance spectra every } 8 \mathrm{~s} \\
\sim 1300000 \text { observations per day }\end{array}$ \\
\hline Lifetime & 5 years \\
\hline
\end{tabular}

$0.2 \mathrm{~K}$ for wavenumbers lower than $2200 \mathrm{~cm}^{-1}$, except for the narrow portion between 1800 and $2000 \mathrm{~cm}^{-1}$ where it approaches $0.3 \mathrm{~K}$ (see Fig. 2). As a guideline to these high performances, the noise is well below $0.1 \mathrm{~K}$ between 1150 and $1500 \mathrm{~cm}^{-1}$. It starts to increase above $2500 \mathrm{~cm}^{-1}$, where the TIR emission drops. The current radiometric performances are better by a factor of about 2 compared to the pre-flight specifications in several spectral ranges.

The spectral resolution is driven by the FTS optical path difference, which is $2 \mathrm{~cm}$. This leads to a spectral resolution (full width at half maximum) varying between 0.35 and $0.5 \mathrm{~cm}^{-1}$ depending on the wavelength. For convenience, the standard radiance (Level 1C) products are apodized by a Gaussian function of $0.5 \mathrm{~cm}^{-1}$ full width at half maximum, which can be considered as the apodized spectral resolution. Each spectrum is sampled every $0.25 \mathrm{~cm}^{-1}$, providing a total of 8461 radiance channels.

\subsection{Data distribution}

The IASI mission delivers about 1300000 spectra per day. The acquisition of one complete across track scan of IASI, including onboard calibration, takes $8 \mathrm{~s}$. This corresponds to $120(30 \times 4)$ interferograms. On-board processing allows the reduction of the data rate from 45 Megabits per second (interferograms) to $1.5 \mathrm{Megabits}$ per second (spectra). These spectra are down-linked from the satellite to the ground in near real time (about $3 \mathrm{~h}$ after acquisition). The IASI prod-

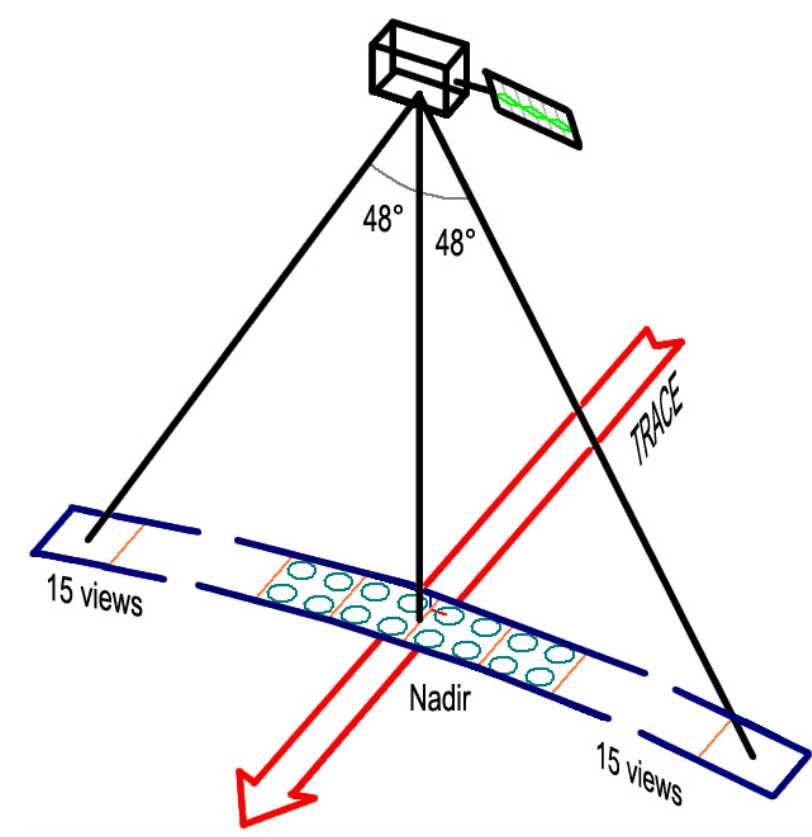

Fig. 1. IASI observing mode: the instrument measures the spectrum of infrared radiation emitted by the Earth and the atmosphere, from a low altitude sun-synchronous orbit, over a swath width of $\sim 2200 \mathrm{~km}$, every $50 \mathrm{~km}$ at nadir (with 4 footprints of $12 \mathrm{~km}$ in diameter).

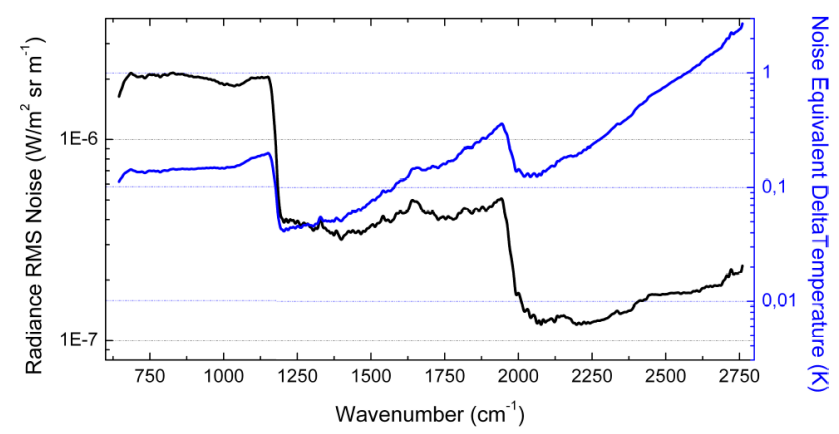

Fig. 2. IASI radiometric noise as established from a set of representative spectra, spanning a range of latitude. Values are provided in radiance units $\left(\mathrm{W} /\left(\mathrm{m}^{2} \mathrm{sr} \mathrm{m}^{-1}\right)\right.$, black line, left scale), and were converted to noise equivalent temperature difference $(\mathrm{Ne} \Delta T$, blue line, right scale) for a given reference temperature of $280 \mathrm{~K}$.

ucts are operationally distributed via Eumetsat's Data Distribution System (EumetCast). EumetCast uses the services of a satellite operator and a telecommunication provider to distribute the data files to a wide audience located within a geographical coverage zone which includes most of Europe and certain locations in Africa. EumetCast has distributed Level 1C radiance data since June 2007, geophysical Level 2 products such as temperature, water vapour profiles, surface and cloud properties since September 2007 (Schlüssel et al., 2005), as well as total and partial columns for trace gases since March 2008 (August et al., 2009). 


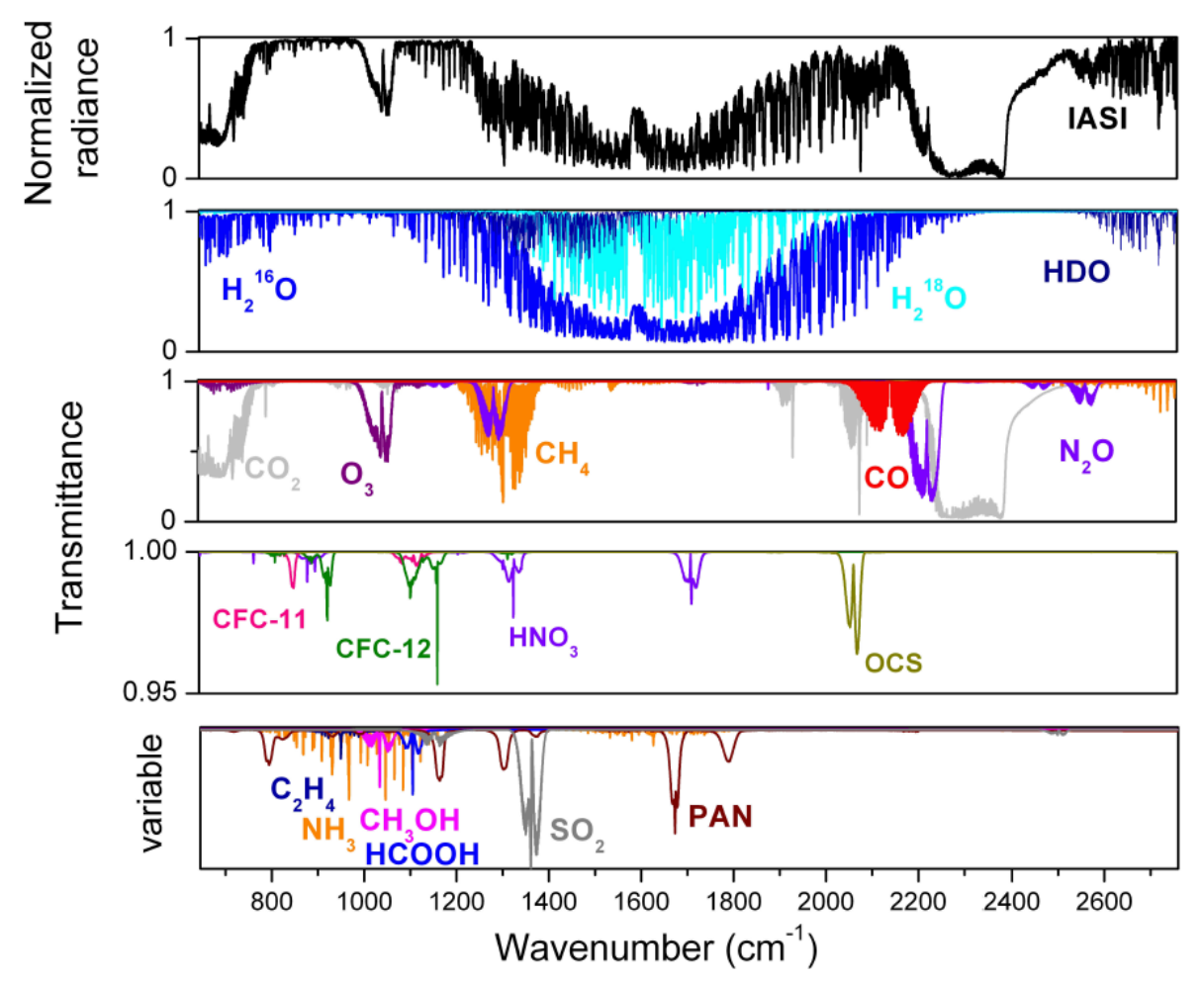

Fig. 3. Top panel: radiance atmospheric spectrum (in normalized units) recorded by IASI/MetOp, over West of Australia, on 20 December, 2006. Middle panels: radiative transfer transmittance simulations to identify the main absorbing gases (middle panels) and the weaker absorbers (lower panel, with a variable scale). All the species indicated on the plot have been detected by IASI, although not all in this particular observation, as some are only detectable when special events occur, such as fires or volcanic eruptions.

\section{Trace gas measurements}

\subsection{Atmospheric spectra and geophysical products}

Atmospheric sounding using the TIR spectral range relies on the analysis of atmospheric radiance spectra. The radiance signal recorded by the instrument in orbit is a composite of the initial longwave infrared emission (the Earth black body emission at the location of the measurement), modified for cloud free scenes by gaseous absorption and emission processes along the path. Each molecule has a specific signature resulting from rotation-vibration transitions. Concentrations can be retrieved for each molecule absorbing in the atmospheric path using iterative inversion methods. Figure 3 provides an example of a IASI spectrum in normalized radiance (radiance divided by the local Earth's blackbody function), along with the individual molecular absorption contributions that have been identified up to now. A complete list of these geophysical Level 2 products, which have been analyzed by several groups, is provided in Table 2, with adequate referencing to published papers. From these absorbing species four classes of compounds can be distinguished:
1. Absorbers with long lifetimes ( $>50$ years) and stable atmospheric concentrations, which require accurate retrievals in order to provide useful information on their global or temporal variability (accuracy lower than a few percents is required). These are principally the strongly absorbing climate gases, namely, carbon dioxide $\left(\mathrm{CO}_{2}\right)$ and nitrous oxide $\left(\mathrm{N}_{2} \mathrm{O}\right)$. The retrieval of their concentration from IASI observations requires very specific methods, which are not reported in this paper. Additional information can be found in Crevoisier et al. (2009a) and Ricaud et al. (2009) for $\mathrm{CO}_{2}$ and $\mathrm{N}_{2} \mathrm{O}$, respectively. A similar situation is observed for the weakly absorbing chlorofluorocarbons CFC-11 and CFC-12, which still exhibit significant absorption signatures in IASI spectra despite being regulated by the Montreal protocol. HCFC-22, the most abundant substitute of chlorofluorocarbons, is also detectable. Additionally the long-lived carbonyl sulphide molecule (OCS) is identified in the spectra (Shephard et al., 2009).

2. Strong to medium absorbers which exhibit a significant atmospheric variability ( $>5 \%$ ) because of their reactivity (lifetimes from a few weeks to a few years), which can be observed in each individual IASI observation. 
Table 2. List of products available from the IASI mission. For each molecule, when available, the estimated vertical resolution (DOFS, independent information on the vertical), and accuracy are provided. Long and medium lived species are observed in each spectrum, while the short lived species are only detected over specific events or close to emission sources.

\begin{tabular}{|c|c|c|c|c|}
\hline Species & Vertical Res. (DOFS) & Error $(\%)$ & Comment & References \\
\hline \multicolumn{5}{|c|}{ Long-lived species (lifetime $>10$ years) } \\
\hline $\mathrm{CO}_{2}$ & $<1$ & NA & Strong absorber & Crevoisier et al., 2009a \\
\hline $\mathrm{N}_{2} \mathrm{O}$ & $<1$ & NA & Strong absorber & Ricaud et al., 2009 \\
\hline CFC-11 & $<1$ & NA & Weak absorber & \\
\hline CFC-12 & $<1$ & NA & Weak absorber & \\
\hline HCFC-22 & NA & NA & Weak absorber & \\
\hline OCS & $<1$ & NA & Weak absorber & Shephard et al., 2009 \\
\hline \multicolumn{5}{|c|}{ Medium-lived species (lifetime a few weeks to a few years) } \\
\hline $\mathrm{H}_{2} \mathrm{O}$ & $5-6$ & $15 \%(0-20 \mathrm{~km})$ & Dominant absorber & Herbin et al., 2009 \\
\hline HDO & $3-4$ & $30 \%(0-20 \mathrm{~km})$ & $\begin{array}{l}\text { Strong absorber+absorption } \\
\text { in the backscattered } \\
\text { solar radiation }\end{array}$ & Herbin et al., 2009 \\
\hline $\mathrm{H}_{2}^{18} \mathrm{O}$ & $3-4$ & $\mathrm{NA}$ & Strong absorber & Herbin et al., 2009 \\
\hline $\mathrm{CH}_{4}$ & $\sim 1$ & $\begin{array}{l}<2 \% \\
\text { Tot. col. }\end{array}$ & $\begin{array}{l}\text { Strong absorber+absorption } \\
\text { in the backscattered } \\
\text { solar radiation }\end{array}$ & $\begin{array}{l}\text { Razavi et al., } 2009 \\
\text { Crevoisier et al., 2009b }\end{array}$ \\
\hline $\mathrm{O}_{3}$ & $3-4$ & $\begin{array}{l}30 \%(0-6 \mathrm{~km}) \\
3 \% \text { Tot. col. }\end{array}$ & $\begin{array}{l}\text { Strong absorber with large } \\
\text { stratospheric contribution }\end{array}$ & $\begin{array}{l}\text { Eremenko et al., } 2008 \\
\text { Boynard et al., } 2009 \\
\text { Keim et al., 2009 } \\
\text { Massart et al., } 2009 \\
\text { Amato et al., } 2009\end{array}$ \\
\hline $\mathrm{CO}$ & $1-2$ & $10 \%$ & & $\begin{array}{l}\text { George et al., } 2009 \\
\text { Turquety et al., } 2009\end{array}$ \\
\hline $\mathrm{HNO}_{3}$ & $\sim 1$ & $\begin{array}{l}15 \% \\
\text { Tot. col. }\end{array}$ & $\begin{array}{l}\text { Weak absorber with large } \\
\text { stratospheric contribution }\end{array}$ & Wespes et al., 2009 \\
\hline \multicolumn{5}{|c|}{ Short-lived species (lifetime a few hours to a few days) } \\
\hline $\mathrm{NH}_{3}$ & & NA & $\begin{array}{l}\text { Detected in fires and } \\
\text { over agricultural regions }\end{array}$ & $\begin{array}{l}\text { Coheur et al., } 2009 \\
\text { Clarisse et al., } 2009\end{array}$ \\
\hline $\mathrm{CH}_{3} \mathrm{OH}$ & & NA & Detected in fires & Coheur et al., 2009 \\
\hline $\mathrm{HCOOH}$ & & NA & Detected in fires & Coheur et al., 2009 \\
\hline $\mathrm{C}_{2} \mathrm{H}_{4}$ & & NA & Detected in fires & Coheur et al.,2009 \\
\hline $\mathrm{SO}_{2}$-volcans & & NA & $\begin{array}{l}\text { Detected in volcanic } \\
\text { plumes for concentrations } \\
\text { above } 2 \mathrm{DU}\end{array}$ & Clarisse et al., 2008 \\
\hline \multicolumn{5}{|l|}{ Aerosols } \\
\hline $\begin{array}{l}\text { Dust (sand), volcanic } \\
\text { ash, ice clouds }\end{array}$ & $\sim 1$ & NA & & $\begin{array}{l}\text { L. Clarisse et al., persona } \\
\text { communication, } 2009\end{array}$ \\
\hline
\end{tabular}

These species, which contribute to tropospheric and/or stratospheric chemistry, are water vapour $\left(\mathrm{H}_{2} \mathrm{O}\right.$ and isotopologues $\mathrm{HDO}$ and $\left.\mathrm{H}_{2}^{18} \mathrm{O}\right)$, methane $\left(\mathrm{CH}_{4}\right)$, ozone $\left(\mathrm{O}_{3}\right)$, carbon monoxide $(\mathrm{CO})$, and nitric acid $\left(\mathrm{HNO}_{3}\right)$. More details on their measurements and on the geophysical analyses of the retrieved concentration fields are provided in the next section, and in several specialized papers of this issue (Herbin et al., 2009; Razavi et al., 2009; Boynard et al., 2009; Keim et al., 2009; George et al., 2009; Fortems-Cheiney et al., 2009; Turquety et al., 2009; Wespes et al., 2009). 
3. Weak absorbers that can only be detected above emission sources or in concentrated plumes owing to the good radiometric performance of IASI. These include sulphur dioxide $\left(\mathrm{SO}_{2}\right)$ from volcanoes (Clarisse et al., 2008), ammonia $\left(\mathrm{NH}_{3}\right)$ from biomass burning and intensive land use (Clarisse et al., 2009) and volatile organic compounds such as formic acid $(\mathrm{HCOOH})$, methanol $\left(\mathrm{CH}_{3} \mathrm{OH}\right)$, ethene $\left(\mathrm{C}_{2} \mathrm{H}_{4}\right)$ and peroxyacetyl nitrate $\left(\mathrm{CH}_{3} \mathrm{COONO}_{2}\right.$, abbreviated as PAN) from biomass burning (Coheur et al., 2009). Note that all these compounds are in the $800-1200 \mathrm{~cm}^{-1}$ atmospheric window, where contamination from water vapour is reduced.

4. Higher altitude aerosols, such as those resulting from sandstorms, volcanic eruptions or cirrus formation. They mainly manifest themselves in the 700$1300 \mathrm{~cm}^{-1}$ window as broad absorption features.

\subsection{IASI processing of trace species at LATMOS and ULB}

In this section we limit the description to work that was performed at LATMOS and ULB for the analysis of IASI spectra in order to derive atmospheric concentrations of trace gases.

\subsubsection{Cloud filtering}

For cloud free situations, nadir looking TIR instruments can measure the atmospheric radiation down to the ground and, for some species, vertical information can be derived, provided ground emissivity, surface temperature and atmospheric temperature are known at the location of the measurement. For species that are optically thin total columns are retrieved, and for species like water vapour or ozone, for which at least some lines are optically thick, profiles can be retrieved.

When a cloud is present in the optical path, the radiance signal recorded by the instrument can be significantly affected, depending on the type (water or ice cloud) and the optical thickness of the cloud. Only the data that are not or weakly contaminated by clouds in the field of view (FOV) were selected for further processing (about 700000 data per day, on average).

Before the availability of Level 2 Eumetsat data, at the end of September 2007, we relied on a basic cloud filtering system (Hadji-Lazaro et al., 2001) based on the European Centre for Medium-Range Weather Forecasts (ECMWF) analysis (interpolated in time and space to match the observation) for the surface skin temperature $\left(T_{s}\right)$. The filter uses the comparison between the brightness temperatures at 11 and $12 \mu \mathrm{m}$ (BT11 and BT12) with $T_{s}$. We consider spectra as "clear" when differences between $T_{s}$, BT11 and BT12 are lower than $15 \mathrm{~K}$ in absolute value.

When the Level 2 temperature and cloud information became available, the data treatment was adapted to make full use of these products. These include cloud fraction in the IASI pixel, cloud top temperature, cloud pressure, and cloud phase (IASI Level 2 Product Guide, 2008). These parameters are determined either from IASI in a stand-alone mode or in combination with the ATOVS and AVHRR instruments (Schlüssel et al., 2005). The cloud detection is based on the combined information of the IASI Level 1C spectra and the AMSU-A data. If clouds are detected in the IASI FOV, the $\mathrm{CO}_{2}$-slicing method is used to estimate the fractional cloud cover and the cloud top pressure. If the FOV has been declared cloudy by the AVHRR-derived fractional cloud cover, the average cloud top height and cloud top temperatures are calculated for the number of identified cloud formations. The discrimination between ice clouds, mixed phases, and liquidwater clouds is made using the emission spectrum of the atmosphere between 11 and $12 \mu \mathrm{m}$ that shows a steeper slope for liquid water than for ice clouds. The summary cloud fraction flag (FLG_CLDSUM), which combines information from the different cloud parameters, was used for the analysis of trace gases reported here. All data corresponding to the cloud flag between 0 and $25 \%$ are further analyzed.

\subsubsection{Concentration retrievals}

Inverse methods are used to retrieve the desired concentrations (total column or profile product) from the spectroscopic signatures of atmospheric constituents in the radiance spectrum. The state of the atmosphere is the unknown quantity to be determined, and is a function of local conditions such as pressure and temperature profiles, and surface emissivity. The inverse step method allows the retrieval of concentrations for one or several trace gases simultaneously, provided that there is some prior knowledge of the atmospheric state. The problem remains, however, mostly under-determined and the quantities can only be retrieved using both observations and prior assumptions (that determine the linearization point about which a retrieval is constrained), also taking into account the instrument radiometric noise. The priori assumption in the retrieval process consists ideally of a statistical mean and covariance of the measured atmospheric quantity.

The posterior products include the retrieved quantity (total column or vertical profile for a given species), its associated error covariance and averaging kernel functions that characterize the vertical information content. The peak of each averaging kernel gives the altitude of maximum sensitivity at each retrieved level, whereas its full width at half maximum can be interpreted as the vertical resolution of the retrieval. The trace of the averaging kernel matrix is called the Degree of Freedom of the Signal (DOFS), a convenient quantity to establish the number of independent pieces of information available on the vertical (Rodgers, 2000).

The ULB and LATMOS teams have been working for several years to develop processing tools to retrieve trace gas abundances from TIR sounders, in preparation for IASI. The algorithms were used for the exploitation of data obtained by 
other remote sounders such as the solar occultation Atmospheric Chemistry Experiment (ACE-FTS) instrument (e.g. Coheur et al., 2007; Clerbaux et al., 2008a; Herbin et al., 2009), the nadir looking IMG/ADEOS sounder (e.g. Clerbaux et al., 2003; Coheur et al., 2005; Barret et al., 2005; Herbin et al., 2007), and the TES/AURA FTS (Clerbaux et al., 2008b).

Systematic retrievals of trace gas species started as soon as the IASI Level 1C data became available. Datasets of more than 18 months duration are available, from which global and local distributions of trace gases have been routinely derived using several sophisticated programs depending on the application (global maps, local profiles, or detection of special events). A short description of the processing tools is provided hereafter:

1. Near real time global scale distribution maps are derived for ozone using a neural network (NN) based algorithm (see Turquety et al., 2004, for a full description). This $\mathrm{NN}$ also provides total columns of $\mathrm{CO}$ and $\mathrm{CH}_{4}$, which have not yet been considered for further geophysical analyses. It is worth noting that the core of the $\mathrm{NN}$ algorithm was implemented at the Eumetsat ground segment to generate operational Level 2 trace gases data for ozone $(0-6 \mathrm{~km} ; 0-12 \mathrm{~km} ; 0-16 \mathrm{~km}$ and total column content), $\mathrm{CO}$ and $\mathrm{CH}_{4}$ total columns, but the training dataset differs from ours, and the current products distributed by EumetCast are different from those described here. In parallel, a fast retrieval approach based on the optimal estimation theory has been developed (FORLI: Fast Operational/Optimal Retrieval on Layers for IASI) to provide in near real time global distributions of CO vertical profiles (George et al., 2009; Turquety et al., 2009) and of $\mathrm{HNO}_{3}$ total columns (Wespes et al., 2009).

2. Local profile retrievals are performed using the Atmosphit software (Coheur et al., 2005), which contains a full line-by-line radiative transfer model and which relies on the optimal estimation to derive profiles and associated averaging kernels.

3. Detection of weak absorbers is performed routinely by using the difference in brightness temperature (BTD) between selected and reference window channels (Clarisse et al., 2009). This provides a simple and robust means to probe the presence of absorption and/or emission features in the spectra and is a useful tool for the identification and tracking of sudden events such as fires and volcanic plumes (Clarisse et al., 2008; Coheur et al., 2009).

\subsubsection{Examples of trace gas distributions}

Figure 4 illustrates the results from the routinely retrieved global concentrations for some key atmospheric products of the IASI mission. The figure is a composite of measurements of different species, obtained during a ten day observation period extending from August 18 to August 28 (2008). The concentration maps were generated using the different ULB-LATMOS retrieval algorithms described above, along with EumetCast distributed products for temperature and water vapour content. The methane retrieval is obtained using Atmosphit, and a description of the product may be found in Razavi et al. (2009). CO total columns are operationally derived using FORLI-CO, and a comparison of this product with similar products obtained by other TIR remote sensors is provided in George et al. (2009). In depth analysis of CO emitted by fire events is reported in Turquety et al. (2009) and an estimation of global emission sources is provided in Fortems-Cheinet et al. (2009). Ozone total and tropospheric columns were generated from the NN algorithm, and validation of these products with GOME-2 data and assimilation of other satellite data are discussed in Boynard et al. (2009) and Massart et al. (2009), respectively. The $\mathrm{HNO}_{3}$ distribution fields are described in Wespes et al. (2009). The ammonia distribution was obtained by mapping BTDs to total column abundances, as described elsewhere (Clarisse et al., 2009). A similar procedure was used to derive the $\mathrm{SO}_{2}$ distribution (see Clarisse et al., 2008), which corresponds to the plume of the Kasatochi eruption in early August averaged over the ten days analysis period. Volcanic eruptions are indeed identified and tracked using the $\mathrm{SO}_{2}$ spectral signatures. Based on this, ULB is also running a near-real time $\mathrm{SO}_{2}$ alert system since November 2008. The alerts are sent out by email and complemented by images directly available on the web (http://cpm-ws4.ulb.ac.be/Alerts/). This website can also be consulted to retrieve information on older events.

From the IASI measurements, daily, monthly and seasonal global scale maps can be derived. As an example, the seasonal variation of $\mathrm{CO}$ is shown in Fig. 5. It provides a representation of the $\mathrm{CO}$ total column product as observed for different months of the year. It corresponds to daytime total column observations, averaged over a month (for further description, see George et al., 2009). In the Northern hemisphere, most of the pollution is associated with urban activity, with persistent high values above China and elevated levels over USA, Europe and Asia in spring. In the tropics and Southern Hemisphere, most of the CO is emitted where biomass burning occurs, such as in Africa, and Central and South America (following the seasonal shift in the InterTropical Convergence Zone). Owing to the excellent global coverage of the instrument, when averaging over several days the gaps due to cloud contaminated pixels that were excluded from the processing disappear. From these plots it can be seen that the $\mathrm{CO}$ pollution plumes emitted locally spread from regional to global scales, depending on meteorological conditions and photochemistry. CO quick-look distributions daily maps with different projections can be viewed from the LATMOS website at http://iasi-chem.aero.jussieu.fr. This $\mathrm{CO}$ product is now operationally assimilated in the GEMS 

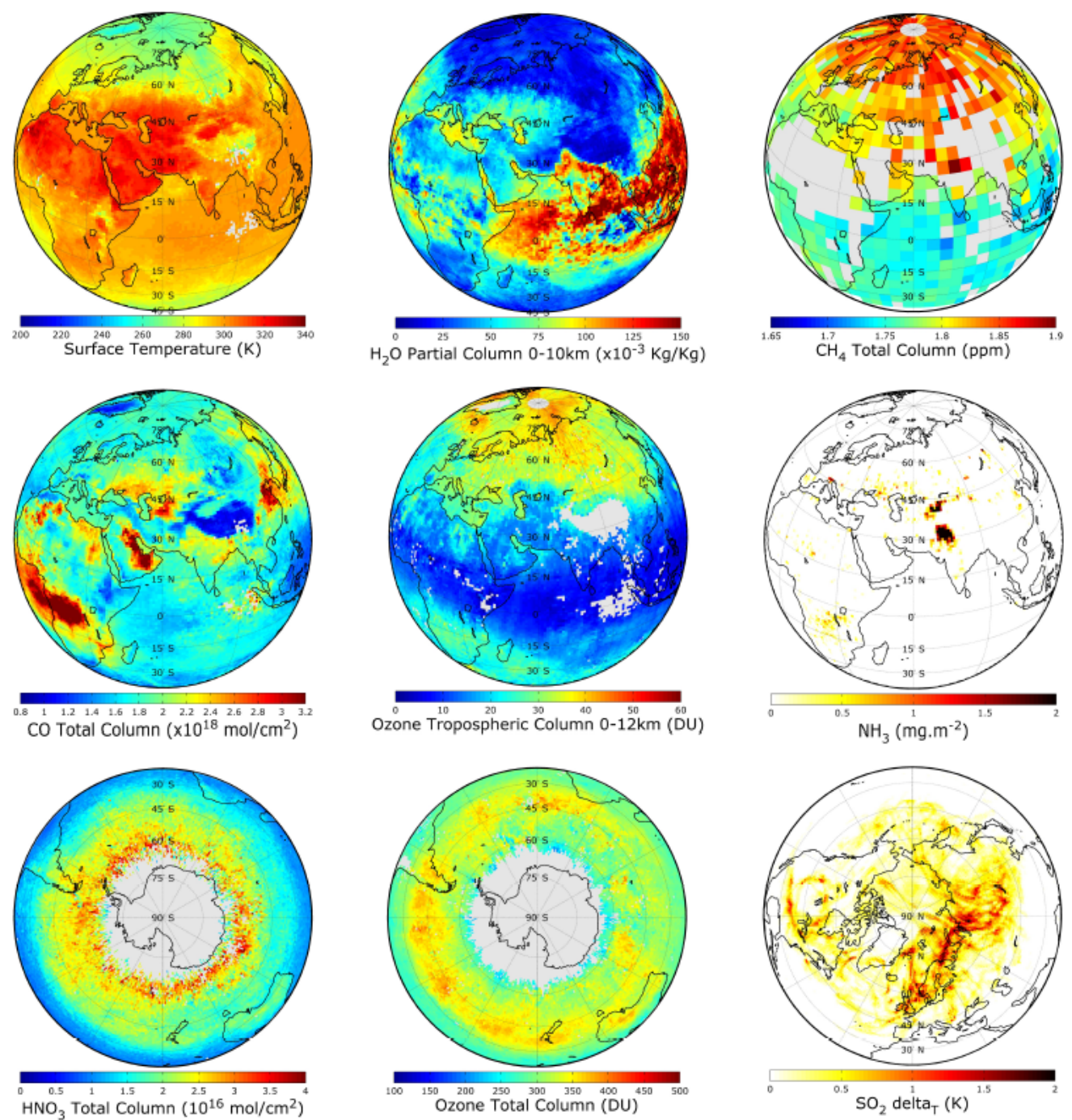

Fig. 4. Distributions as retrieved from IASI, averaging over ten days of observations in August 2008 (18-28). The orientation of the globe was chosen in order to highlight the most relevant atmospheric processes. From left to right and from top to bottom, these are in a projection highlighting Europe-Africa-Asia surface temperature and $\mathrm{H}_{2} \mathrm{O}$ partial columns $(0-10 \mathrm{~km}$, in kg/kg units) from the Eumetsat Level 2 products, $\mathrm{CH}_{4}$ normalized mixing ratio from Atmosphit (total methane content divided by the $\mathrm{N}_{2} \mathrm{O}$ total column), CO total columns from FORLI-CO, $\mathrm{O}_{3}$ tropospheric columns from $\mathrm{NN}$ and $\mathrm{NH}_{3}$ from Atmosphit. The last row shows in a polar projection over the Antarctic $\mathrm{O}_{3}$ and $\mathrm{HNO}_{3}$ total columns from $\mathrm{NN}$ and FORLI respectively, at a time when the depletion of stratospheric ozone starts. The $\mathrm{SO}_{2}$ distribution on the bottom right is shown with an Arctic projection, highlighting the plume from the major Kasatochi eruption that occurred a few days before. Data are binned on a $1^{\circ} \times 1^{\circ}$ grid, except $\mathrm{CH}_{4}$ which is binned on a $5^{\circ} \times 5^{\circ}$ grid (pure nadir observations only). The units are provided on the scales for each product.

ECMWF project (Hollingsworth et al., 2008), to produce a chemical forecast of $\mathrm{CO}$ fields.

Figure 6 illustrates the detection of short-lived species $\left(\mathrm{C}_{2} \mathrm{H}_{4}, \mathrm{CH}_{3} \mathrm{OH}, \mathrm{HCOOH}\right.$ and $\left.\mathrm{NH}_{3}\right)$ for one IASI morning orbit on the 17 May 2008 during large-scale fires in Eastern Mongolia (Warneke et al., 2009). Concentrations were obtained here using the Atmosphit software. Other fire events, in particular the Greek fires that occurred in August 2007, are presented and analyzed in Turquety et al. (2009) and in Coheur et al. (2009).

\subsection{Vertical information and accuracy}

\subsubsection{Thermal contrast}

The sensitivity of TIR sounders to probe the troposphere varies widely according to the temperature of the surface and the atmosphere. Particularly important for studying local emission sources is the difference between the surface temperature and the temperature of the boundary layer. This temperature difference $(\Delta T)$ is often referred to as the thermal 

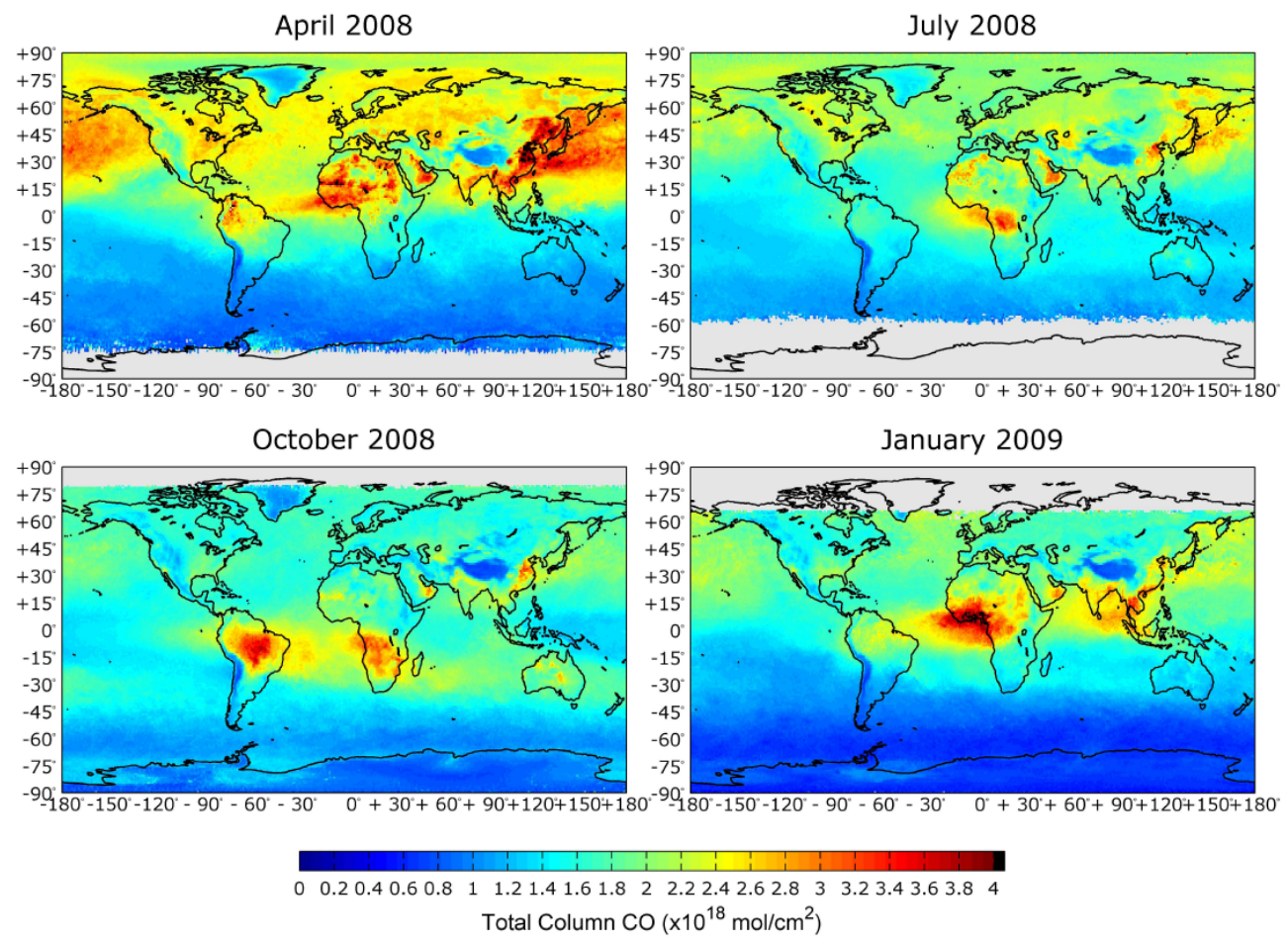

Fig. 5. IASI CO total column measurements. Each map is an average over one month (April, July, October and January, daytime observations only), chosen to highlight the seasonal patterns. It is worth noting that some issues remain in the IASI data treatment for measurements over desert (e.g. Sahara in spring and summer).
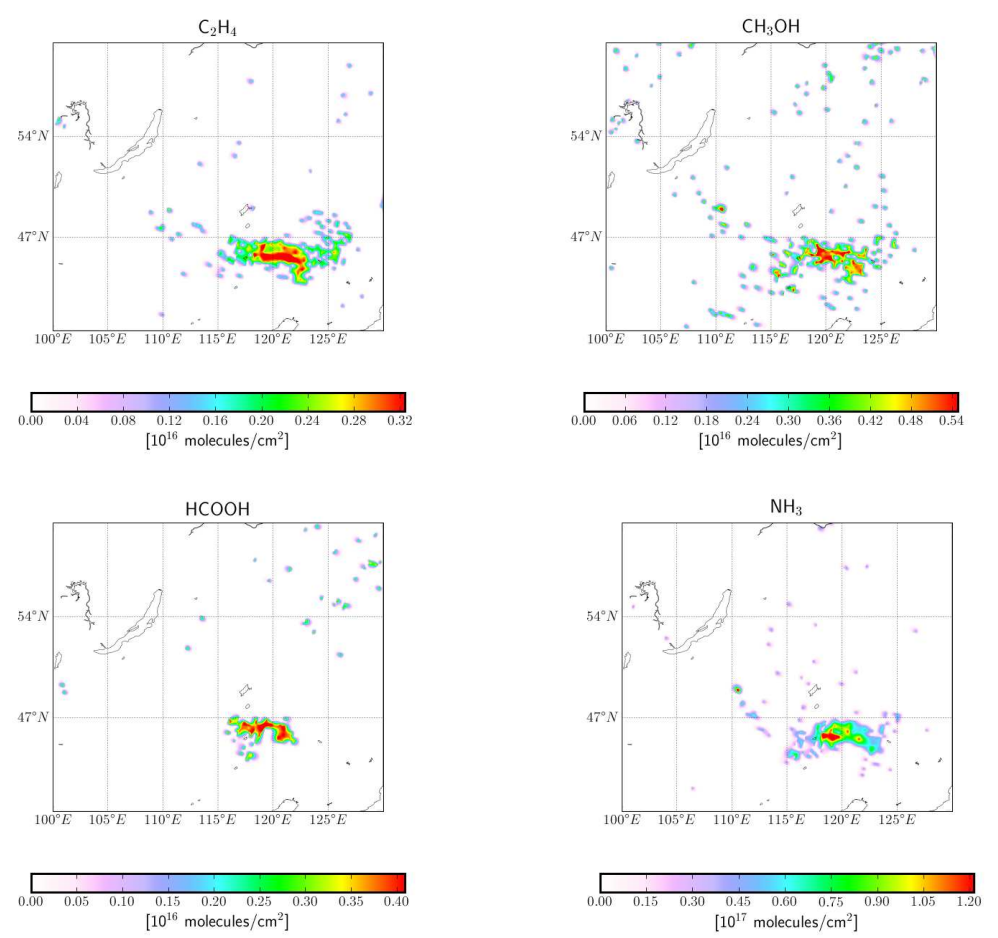

Fig. 6. Fire plume from the Eastern Siberia fires, measured in May 2007, at about 11:00 local time, shown separately from the upper left to the bottom right, for $\mathrm{C}_{2} \mathrm{H}_{4}, \mathrm{CH}_{3} \mathrm{OH}, \mathrm{HCOOH}$ and $\mathrm{NH}_{3}$ total columns, in molecules $/ \mathrm{cm}^{2}$. Data are interpolated on a $0.125^{\circ} \times 0.125^{\circ}$ grid. 

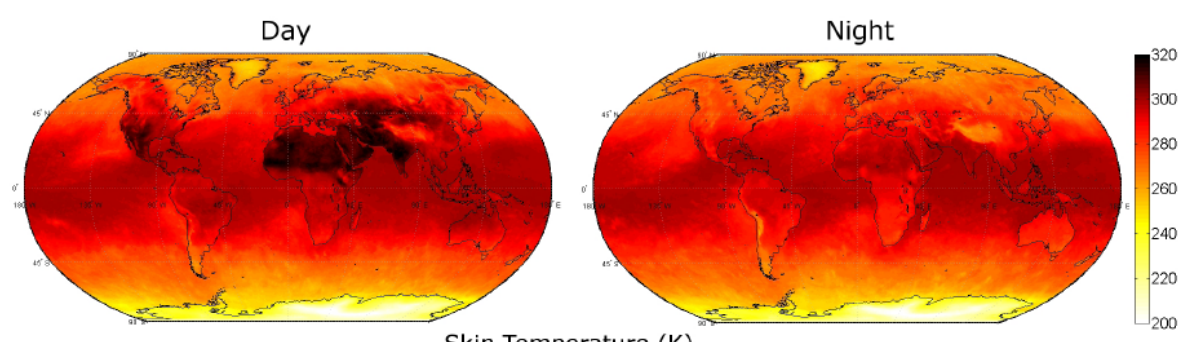

Skin Temperature (K)
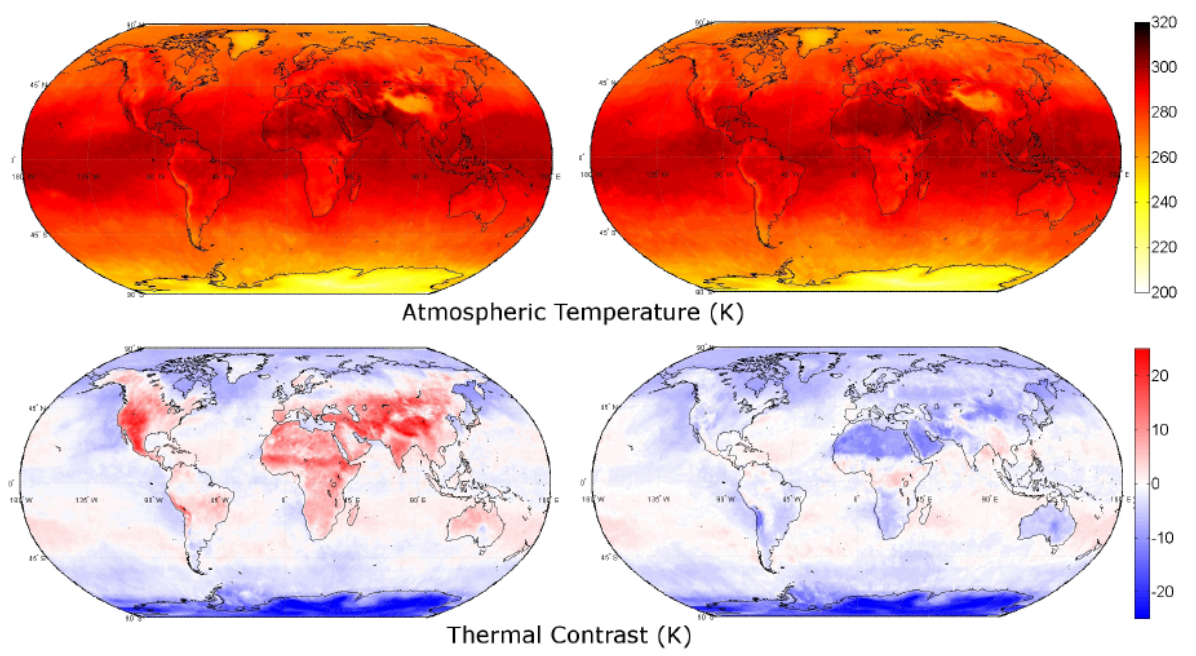

Fig. 7. Upper and middle panels represent skin temperatures and the first level of retrieved temperatures available from Eumetsat Level 2 products, for daytime (left) and nighttime (right) observations, averaged over May 2008. The bottom plots are the difference between these temperatures (thermal contrast).

contrast, a critical parameter for analyzing retrieved products from infrared missions as it determines the shape of the averaging kernel function and if the measurement contains information from the boundary layer or not (e.g. Deeter et al., 2007).

Figure 7 shows the $\Delta T$ distribution derived from IASI observations in May 2007, where skin temperature is the brightness temperature of the surface derived from IASI surface sensitive radiance channels, and $T$ is the temperature of the first level in the temperature profile (where the latter is derived from the analysis of $\mathrm{CO}_{2}$ bands). It is worth noting that these two parameters are retrieved independently. As expected (Prigent et al., 2003; Deeter et al., 2007; Clerbaux et al., 2008c), the thermal contrast exhibits significant geographical, seasonal, and diurnal variability. It is higher during the day than during the night over land, and is usually higher over land than over sea. This day/night difference is a direct consequence of the surface heating associated with the absorption of solar radiation: in the morning at sunrise the Earth starts absorbing ultraviolet-visible radiation, for which the atmosphere is roughly transparent. The Earth then transmits this energy into the atmosphere via infrared radiation, which heats up later, resulting in a positive thermal contrast. When the sun sets the Earth cools itself by releasing radiation into the atmosphere. This in turn continues to heat the atmo- sphere for some time, thus lessening the thermal contrast. These processes are amplified above land by the fact that the surface of the Earth has a limited heat capacity and thus heats up/cools down faster than the atmosphere, causing high thermal contrast variations above the continents. Locally, surface skin temperatures are also modulated by both vegetation and soil moisture, through processes of evapotranspiration and evaporation. Therefore dry, sparsely vegetated regions typically offer stronger daytime thermal contrast conditions than heavily vegetated regions. Over sea the diurnal variations of surface temperature is limited because of the much larger heat capacity of sea water.

\subsubsection{Vertical information and accuracy}

The direct consequence of thermal contrast variations is that the IASI instrument provides more surface sensitive measurements and to some extent better vertical resolution for the morning overpass and over land. It also explains why one often observes a marked transition in the concentration distribution in the measurements at the edge of a continent (e.g. see Fig. 5). The influence of thermal contrast conditions appears in the averaging kernels associated with concentration retrievals, and allows the analysis of the representativeness of the observation at different altitudes. Over 
oceans and during the night, retrieved concentration products for species that are emitted at the surface level are generally dominated by concentrations in the mid-troposphere because of low thermal contrast. This is not the case for $\mathrm{O}_{3}$ and $\mathrm{HNO}_{3}$ total columns, as for these two the dominant contribution comes from the stratosphere. Over land and for the morning overpass, if vegetation is sparse at this location, IASI has the capability to sound deeper up into the boundary layer (also see Turquety et al., 2009, for further discussion). Its ability to probe the planetary boundary layer, where local pollution occurs, therefore strongly depends on location, temperature, type of surface and time of the day. The thermal contrast between the surface and the planetary boundary layer determines to what extent the surface sources, in particular of short lived species, can be detected.

Table 2 provides a summary of our current assessment for vertical information content and accuracy, for the range of molecules that are measured from the IASI spectra. Details on the reported values can be found in the references mentioned in the Table. It is worth noting that accuracy values are indicative values, as they strongly depend on the geographical location of the observation. Some of the species reported in the Table are detectable only for some specific conditions, combining high emissions and favourable thermodynamic conditions.

\section{Conclusions and discussion}

Satellites can sample the whole planet and complement the in-situ ground stations network in order to provide global scale monitoring of atmospheric composition and to provide the observations that feed atmospheric chemistry models for air quality forecasts. In the framework of the European GMES initiative, new space-borne instruments are currently being designed to be part of the Earth observation space segment that will deliver air quality measurements in support of policy decisions after 2018. As near real time and frequent observations are required, current plans are to combine meteorological payloads with atmospheric chemistry sounders that use both the UV-visible and the TIR spectral range, from both polar and geostationary orbits (e.g. Stuhlmann et al., 2005).

The MetOp satellite launched in 2006 is a pioneering platform, which delivers near real time ( $\sim 3 \mathrm{~h}$ after observation) operational products both for weather forecasting and atmospheric chemistry monitoring (with IASI and GOME-2 onboard), and will provide measurements for 15 years (20062020). IASI delivers about 1300000 atmospheric spectra per day from which the concentration of a series of trace gases spanning a range of lifetimes can be retrieved. In this paper we have reviewed the latest developments that have been performed at ULB and LATMOS in order to generate systematic global scale distributions for $\mathrm{CO}, \mathrm{CH}_{4}, \mathrm{O}_{3}$ (total and tropospheric), $\mathrm{HNO}_{3}$, and $\mathrm{NH}_{3}$. We have also shown that due to the excellent radiometric performance of the instrument, local distributions of organic species measured during fire events, such as $\mathrm{C}_{2} \mathrm{H}_{4}, \mathrm{CH}_{3} \mathrm{OH}, \mathrm{HCOOH}$, and PAN are possible. Not all these products are available in near real time yet, but extended data sets for further scientific analysis are available upon request (cathy.clerbaux@latmos.ipsl.fr). All products are currently being validated, but we lack rapid delivery of ground-based data for example. Retrieval algorithms will be continuously improved, by comparing our observations with other similar datasets when available.

IASI provides limited information on the vertical and in particular of the boundary layer, the extent of which depends upon local surface properties and thermodynamic conditions. We have discussed how thermal contrast conditions impact on the observation and determines the sensitivity of the measurement at different altitudes, including near the surface.

The availability of data in near real time makes them valuable input to help in the detection and prediction of pollution episodes. The CO total column product is currently assimilated at ECMWF in the framework of the GEMS project to provide the $\mathrm{CO}$ global forecast. Work is in progress to assimilate the $\mathrm{O}_{3}[0-12 \mathrm{~km}]$ column product in the Chimere (Rouil et al., 2009) French air quality forecast model, and to improve global emission inventories using IASI's ammonia observations (Clarisse et al., 2009). Finally, the synergetic use of GOME-2 and IASI ozone products in order to obtain improved tropospheric ozone distribution is underway in the framework of the Eumetsat's Satellite Application Facility on Ozone and Atmospheric Chemistry Monotoring $\left(\mathrm{O}_{3} \mathrm{M}-\right.$ SAF).

Acknowledgements. The IASI mission is a joint mission of Eumetsat and the Centre National d'Etudes Spatiales (CNES, France). The IASI L1 data are distributed in near real time by Eumetsat through the Eumetcast system distribution. The authors acknowledge the Ether French atmospheric database (http://ether.ipsl.jussieu.fr) for providing the IASI L1C data. The French scientists are grateful to CNES for scientific collaboration and financial support. L. Clarisse and P. F. Coheur are respectively Scientific Research Worker (Collaborateur Scientifique) and Research Associate (Chercheur Qualifié) with F.R.S.-FNRS. The research in Belgium was funded by the F.R.S.-FNRS (M.I.S. F.4511.08), the Belgian State Federal Office for Scientific, Technical and Cultural Affairs and the European Space Agency (ESA-Prodex arrangements C90-327). Financial support by the "Actions de Recherche Concertées" (Communauté Française de Belgique) is also acknowledged. The authors would like to thank A. Depauw and C. Scannell for their assistance. We are grateful to INSU for publication support.

Edited by: T. Wagner 


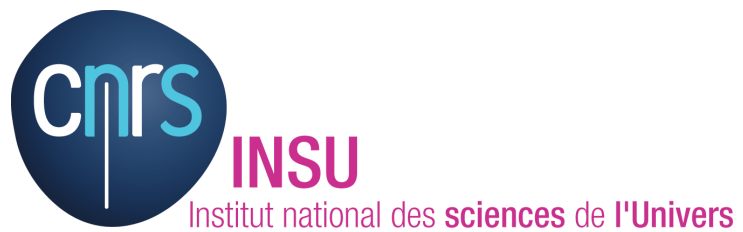

The publication of this article is financed by CNRS-INSU.

\section{References}

Amato, U., Antoniadis, A., De Feis, I., Masiello, G., Matricardi, M., and Serio, C.: Technical Note: Functional sliced inverse regression to infer temperature, water vapour and ozone from IASI data, Atmos. Chem. Phys., 9, 5321-5330, 2009,

http://www.atmos-chem-phys.net/9/5321/2009/.

August, T., Schlüssel, P., Munro, R., Calbet, X., Oduleye, O., Arriaga, A., Hultberg1, T., Hadji-Lazaro, J., Turquety, S., and Clerbaux, C.: ANN ozone retrieval within the operational level 2 processor, Proceedings of the Eumetsat Conference, Darmstadt, 2009.

Barret, B., Turquety, S., Hurtmans, D., Clerbaux, C., Hadji-Lazaro, J., Bey, I., Auvray, M., and Coheur, P.-F.: Global carbon monoxide vertical distributions from spaceborne high-resolution FTIR nadir measurements, Atmos. Chem. Phys., 5, 2901-2914, 2005, http://www.atmos-chem-phys.net/5/2901/2005/.

Blumstein, D., Chalon, G., Carlier, T., Buil, C., Hébert, P., Maciaszek, T., Ponce, G., Phulpin, T., Tournier, B., and Siméoni, D.: IASI instrument: Technical Overview and measured performances, SPIE Denver, 5543-22, 2004.

Boynard, A., Clerbaux, C., Coheur, P.-F., Hurtmans, D., Turquety, S., George, M., Hadji-Lazaro, J., Keim, C., and Meyer-Arnek, J.: Measurements of total and tropospheric ozone from IASI: comparison with correlative satellite and ozonesonde observations, Atmos. Chem. Phys. Discuss., 9, 10513-10548, 2009, http://www.atmos-chem-phys-discuss.net/9/10513/2009/.

Callies, J., Corpaccioli, E., Eisinger, M., Hahne, A., and Lefebvre, A.: GOME-2 - Metop's Second Generation sensor for Operational Ozone Monitoring, ESA Bulletin, 102, 2000.

Cayla, F. R: IASI infrared interferometer for operations and research, in: High Spectral Resolution Infrared Remote Sensing for Earth's Weather and Climate Studies, edited by: Chedin, A., Chahine, M. T., and Scott, N. A., NATO ASI Series, vol. I, 9, Springer Verlag, Berlin, 1993.

Clarisse, L., Coheur, P. F., Prata, A. J., Hurtmans, D., Razavi, A., Phulpin, T., Hadji-Lazaro, J., and Clerbaux, C.: Tracking and quantifying volcanic $\mathrm{SO}_{2}$ with IASI, the September 2007 eruption at Jebel at Tair, Atmos. Chem. Phys., 8, 7723-7734, 2008, http://www.atmos-chem-phys.net/8/7723/2008/.

Clarisse, L., Clerbaux, C., Dentener, F., Hurtmans, D., and Coheur, P. F.: Global ammonia distribution derived from infrared satellite observations, Nature Geosci., 2, 479-483, doi:10.1038/ngeo551, 2009.

Clerbaux, C., Hadji-Lazaro, J., Turquety, S., Mégie, G., and Coheur, P.-F.: Trace gas measurements from infrared satellite for chemistry and climate applications, Atmos. Chem. Phys., 3, 14951508, 2003,

http://www.atmos-chem-phys.net/3/1495/2003/.
Clerbaux, C., George, M., Turquety, S., Walker, K. A., Barret, B., Bernath, P., Boone, C., Borsdorff, T., Cammas, J. P., Catoire, V., Coffey, M., Coheur, P.-F., Deeter, M., De Mazire, M., Drummond, J., Duchatelet, P., Dupuy, E., de Zafra, R., Eddounia, F., Edwards, D. P., Emmons, L., Funke, B., Gille, J., Griffith, D. W. T., Hannigan, J., Hase, F., Höpfner, M., Jones, N., Kagawa, A., Kasai, Y., Kramer, I., Le Flochmoën, E., Livesey, N. J., LópezPuertas, M., Luo, M., Mahieu, E., Murtagh, D., Nédélec, P., Pazmino, A., Pumphrey, H., Ricaud, P., Rinsland, C. P., Robert, C., Schneider, M., Senten, C., Stiller, G., Strandberg, A., Strong, K., Sussmann, R., Thouret, V., Urban, J., and Wiacek, A.: CO measurements from the ACE-FTS satellite instrument: data analysis and validation using ground-based, airborne and spaceborne observations, Atmos. Chem. Phys., 8, 2569-2594, 2008a, http://www.atmos-chem-phys.net/8/2569/2008/.

Clerbaux, C., Coheur, P.-F., Clarisse, L., Hadji-Lazaro, J., Hurtmans, D., Turquety, S., Bowman, K., Worden, H., and Carn, S. A.: Measurements of $\mathrm{SO}_{2}$ profiles in volcanic plumes from the NASA Tropospheric Emission Spectrometer (TES), Geophys. Res. Lett., 35, L22807, doi:10.1029/2008GL035566, 2008 b.

Clerbaux, C., Edwards, D. P., Deeter, M., Emmons, L., Lamarque, J.-F., Tie, X. X., Massie, S. T., and Gille, J.: Carbon monoxide pollution from cities and urban areas observed by the Terra/MOPITT mission, Geophys. Res. Lett, 35, L03817, doi:10.1029/2007GL032300, 2008c.

Coheur, P.-F., Barret, B., Turquety, S., Hurtmans, D., Hadji-Lazaro, J., and Clerbaux, C.: Retrieval and characterization of ozone vertical profiles from a thermal infrared nadir sounder, J. Geophys. Res., 110, D24303, doi:10.1029/2005JD005845, 2005.

Coheur, P.-F., Herbin, H., Clerbaux, C., Hurtmans, D., Wespes, C., Carleer, M., Turquety, S., Rinsland, C. P., Remedios, J., Hauglustaine, D., Boone, C. D., and Bernath, P. F.: ACE-FTS observation of a young biomass burning plume: first reported measurements of $\mathrm{C}_{2} \mathrm{H}_{4}, \mathrm{C}_{3} \mathrm{H}_{6} \mathrm{O}, \mathrm{H}_{2} \mathrm{CO}$ and PAN by infrared occultation from space, Atmos. Chem. Phys., 7, 5437-5446, 2007, http://www.atmos-chem-phys.net/7/5437/2007/.

Coheur, P.-F., Clarisse, L., Turquety, S., Hurtmans, D., and Clerbaux, C.: IASI measurements of reactive trace species in biomass burning plumes, Atmos. Chem. Phys., 9, 5655-5667, 2009, http://www.atmos-chem-phys.net/9/5655/2009/.

Crevoisier, C., Chédin, A., Matsueda, H., Machida, T., Armante, R., and Scott, N. A.: First year of upper tropospheric integrated content of $\mathrm{CO}_{2}$ from IASI hyperspectral infrared observations, Atmos. Chem. Phys., 9, 4797-4810, 2009a, http://www.atmos-chem-phys.net/9/4797/2009/.

Crevoisier, C., Nobileau, D., Fiore, A. M., Armante, R., Chédin, A., and Scott, N. A.: A new insight on tropospheric methane in the Tropics first year from IASI hyperspectral infrared observations, Atmos. Chem. Phys. Discuss., 9, 6855-6887, 2009b, http://www.atmos-chem-phys-discuss.net/9/6855/2009/.

Deeter, M. N., Edwards, D. P., Gille, J. C., and Drummond, J. R.: Sensitivity of MOPITT observations to carbon monoxide in the lower troposphere, J. Geophys. Res., 112, D24306, doi:10.1029/2007JD008929, 2007.

Edwards, D. P., Emmons, L. K., Gille, J. C., Chu, A., Attie, J.-L., Giglio, L., Wood, S. W., Haywood, J., Deeter, M. N., Massie, S. T., Ziskin, D. C., and Drummond, J. R.: Satellite-observed pollution from Southern Hemisphere biomass burning, J. Geophys. Res., 111, D14312, doi:10.1029/2005JD006655, 2006. 
Eremenko, M., Dufour, G., Foret, G., Keim, C., Orphal, J., Beekmann, M., Bergametti, G., and Flaud, J.-M.: Tropospheric ozone distributions over Europe during the heat wave in July 2007 observed from infrared nadir spectra recorded by IASI, Geophys. Res. Lett., 35, L18805, doi:10.1029/2008GL034803, 2008.

Fortems-Cheiney, A., Chevallier, F., Pison, I., Bousquet, P., Carouge, C., Clerbaux, C., Coheur, P.-F., George, M., Hurtmans, D., and Szopa, S.: On the capability of IASI measurements to inform about CO surface emissions, Atmos. Chem. Phys. Discuss., 9, 7505-7529, 2009,

http://www.atmos-chem-phys-discuss.net/9/7505/2009/.

Frankenberg, C., Bergamaschi, P., Butz, A., Houweling, S., Meirink, J. F., Notholt, J., Petersen, A., Schrijver, H., Warneke, T., and Aben, I.: Tropical methane emissions: A revised view from SCIAMACHY onboard ENVISAT, Geophys. Res. Lett., 35, L15811, doi:10.1029/2008GL034300, 2008.

George, M., Clerbaux, C., Hurtmans, D., Turquety, S., Coheur, P.F., Pommier, M., Hadji-Lazaro, J., Edwards, D. P., Worden, H., Luo, M., Rinsland, C., and McMillan, W.: Carbon monoxide distributions from the IASI/METOP mission: evaluation with other space-borne remote sensors, Atmos. Chem. Phys. Discuss., 9, 9793-9822, 2009,

http://www.atmos-chem-phys-discuss.net/9/9793/2009/.

Hadji-Lazaro, J., Clerbaux, C., Couvert, P., Chazette, P., and Boonne, C.: Cloud filter for CO retrieval from IMG infrared spectra using ECMWF temperatures and POLDER cloud data, Geophys. Res. Lett., 28(12), 2397-2400, 2001.

Herbin, H., Hurtmans, D., Turquety, S., Wespes, C., Barret, B., Hadji-Lazaro, J., Clerbaux, C., and Coheur, P.-F.: Global distributions of water vapour isotopologues retrieved from IMG/ADEOS data, Atmos. Chem. Phys., 7, 3957-3968, 2007, http://www.atmos-chem-phys.net/7/3957/2007/.

Herbin, H., Hurtmans D., Clarisse L., Turquety S., Clerbaux C., Rinsland C. P., Boone C., Bernath P. F., and Coheur P.F.: Distributions and seasonal variations of tropospheric ethene $\left(\mathrm{C}_{2} \mathrm{H}_{4}\right)$ from Atmospheric Chemistry Experiment (ACE-FTS) solar occultation spectra, Geophys. Res. Lett., 36, L04801, doi:10.1029/2008GL036338, 2009.

Herbin, H., Hurtmans, D., Clerbaux, C., Clarisse, L., and Coheur, P.-F.: $\mathrm{H}_{2}^{16} \mathrm{O}$ and HDO measurements with IASI/MetOp, Atmos. Chem. Phys. Discuss., 9, 9267-9290, 2009, http://www.atmos-chem-phys-discuss.net/9/9267/2009/.

IASI Level 2 Product Guide, EUM/OPS-EPS/MAN/04/0033, v2A, Eumetsat, 12 November 2008.

Hollingsworth, A., Engelen, R. J., Textor, C., Benedetti, A., Boucher, O., Chevallier, F., Dethof, A., Elbern, H., Eskes, H., Flemming, J., Granier, C., Kaiser, J. W., Morcrette, J. J., Rayner, P., Peuch, V. H., Rouil, L., Schultz, M. G., Simmons, A. J., and the GEMS Consortium: Toward a Monitoring and Forecasting System For Atmospheric Composition: The GEMS Project, B. Amer. Meteor. Soc., 89, 1147-1164, 2008.

Keim, C., Eremenko, M., Orphal, J., Dufour, G., Flaud, J.-M., Höpfner, M., Boynard, A., Clerbaux, C., Payan, S., Coheur, P.F., Hurtmans, D., Claude, H., Dier, H., Johnson, B., Kelder, H., Kivi, R., Koide, T., López Bartolomé, M., Lambkin, K., Moore, D., Schmidlin, F. J., and Stübi, R.: Tropospheric ozone from IASI: comparison of different inversion algorithms and validation with ozone sondes in the northern middle latitudes, Atmos. Chem. Phys. Discuss., 9, 11441-11479, 2009, http://www.atmos-chem-phys-discuss.net/9/11441/2009/.

Martin, R. V.: Satellite remote sensing of surface air quality, Atmos. Environ., 42(34), 7823-7843, 2008.

Massart, S., Clerbaux, C., Cariolle, D., Piacentini, A., Turquety, S., and Hadji-Lazaro, J.: First steps towards the assimilation of IASI ozone data into the MOCAGE-PALM system, Atmos. Chem. Phys., 9, 5073-5091, 2009,

http://www.atmos-chem-phys.net/9/5073/2009/.

Prigent, C., Aires, F., and Rossow, W. B.: Land surface skin temperatures from a combined analysis of microwave and infrared satellite observations for an all-weather evaluation of the differences between air and skin temperatures, J. Geophys. Res., 108(D10), 4310, doi:10.1029/2002JD002301, 2003.

Razavi, A., Clerbaux, C., Wespes, C., Clarisse, L., Hurtmans, D., Payan, S., Camy-Peyret, C., and Coheur, P. F.: Characterization of methane retrievals from the IASI space-borne sounder, Atmos. Chem. Phys. Discuss., 9, 7615-7643, 2009,

http://www.atmos-chem-phys-discuss.net/9/7615/2009/.

Ricaud, P., Attié, J.-L., Teyssédre, H., El Amraoui, L., Peuch, V.H., Matricardi, M., and Schluessel, P.: Equatorial total column of nitrous oxide as measured by IASI on MetOp-A: implications for transport processes, Atmos. Chem. Phys., 9, 3947-3956, 2009, http://www.atmos-chem-phys.net/9/3947/2009/.

Richter, A., Burrows, J. P., Nü, H., Granier, C., and Niemeier, U.: Increase in tropospheric nitrogen dioxide over China observed from space, Nature, 437, 129-132 doi:10.1038/nature04092, 2005.

Rodgers, C. D.: Inverse methods for atmospheric sounding: theory and practice, Ser. Atmos. Oceanic Planet. Phys., 2, World Sci., Hackensack, NJ, 2000.

Rouil, L., Honore, C. , Vautard, R., Beekmann, M., Bessagnet, B., Malherbe, L., Meleux, F., Dufour, A., Elichegaray, C., Flaud, J.M., Menut, L., Martin, D., Peuch, A., Peuch, V.-H., and Poisson, N.: PREV'AIR: an operational forecasting and mapping system for air quality in Europe, B. Am. Meteor. Soc., 90(1), 73-83, doi:10.1175/2008BAMS2390.1, 2009.

Schlüssel, P., Hultberg, T. H., Phillips, P. L. T., August, T., and Calbet, X.: The operational IASI Level 2 processor, Adv. Space Res., 36, 982, doi:10.1016/j.asr.2005.03.008, 2005.

Shephard, M. W., Clough, S. A., Payne, V. H., Smith, W. L., Kireev, S., and Cady-Pereira, K. E.: Performance of the line-by-line radiative transfer model (LBLRTM) for temperature and species retrievals: IASI case studies from JAIVEx, Atmos. Chem. Phys. Discuss., 9, 9313-9366, 2009,

http://www.atmos-chem-phys-discuss.net/9/9313/2009/.

Stuhlmann, R., Rodriguez, A., Tjemkes, S., Grandell, S., Arriaga, A., Bézy, J.-L., Aminou, D., and Bensi, P.: Plans for EUMETSAT's Third Generation Meteosat geostationary satellite programme, Adv. Space Res., 36, 975-981, 2005.

Turquety, S., Hadji-Lazaro, J., Clerbaux, C., Hauglustaine, D. A., Clough, S. A., Cassé, V., Schlüssel, P., and Mégie, G.: Operational trace gas retrieval algorithm for the Infrared Atmospheric Sounding Interferometer, J. Geophys. Res., 109, D21301, doi:10.1029/2004JD004821, 2004.

Turquety, S., Hurtmans, D., Hadji-Lazaro, J., Coheur, P.-F., Clerbaux, C., Josset, D., and Tsamalis, C.: Tracking the emission and transport of pollution from wildfires using the IASI CO retrievals: analysis of the summer 2007 Greek fires, Atmos. Chem. Phys., 9, 4897-4913, 2009, 
http://www.atmos-chem-phys.net/9/4897/2009/.

Warneke, C., Bahreini, R., Brioude, J., Brock, C. A., de Gouw, J. A., Fahey, D. W., Froyd, K. D., Holloway, J. S., Middlebrook, A., Miller, L., Montzka, S., Murphy, D. M., Peischl, J., Ryerson, T. B., Schwarz, J. P., Spackman, J. R., and Veres, P.: Biomass burning in Siberia and Kazakhstan as an important source for haze over the Alaskan Arctic in April 2008, Geophys. Res. Lett., 36, L02813, doi:10.1029/2008GL036194, 2009.
Wespes, C., Hurtmans, D., Clerbaux, C., Santee, M. L., Martin, R. V., and Coheur, P. F.: Global distributions of nitric acid from IASI/MetOP measurements, Atmos. Chem. Phys. Discuss., 9, 8035-8069, 2009,

http://www.atmos-chem-phys-discuss.net/9/8035/2009/.

Worden, H. M., Bowman, K. W., Worden, J. R., Eldering, A., and Beer, R.: Satellite measurements of the clear-sky greenhouse effect from tropospheric ozone, Nature Geosci., 1, 305308, doi:10.1038/ngeo182, 2008. 